\title{
Tropical Journal of Pathology and Microbiology
}

\section{Clinicopathological spectrum of hysterectomy specimens in a tertiary care hospital- A review of 826 cases}

\author{
J Bosco R. ${ }^{{ }^{*}}$, Sarada V. ${ }^{2}$ \\ DOI: https://doi.org/10.17511/jopm.2020.i01.08 \\ 1* Ronald J Bosco, Assistant Professor, Department of Pathology, Trichy SRM medical College Hospital and Research Centre, Trichy, Tamil \\ Nadu, India. \\ 2 Sarada V., Professor, Department of Pathology, Trichy SRM medical College Hospital and Research Centre, Trichy, Tamil Nadu, India.
}

Introduction: Hysterectomy is one of the most common surgeries performed for common gynaecological indications, but less frequently done for tumors of female genital tract. Abnormal uterine bleeding (AUB) is one of the most common indications for hysterectomy. Histopathology is essential to confirm these common causes, but also helps to identify rare causes and to rule out malignancy. Material and Methods: The present study is a retrospective study done at Trichy SRM medical college hospital with hysterectomies done between January 2018 to November 2019 been included in the study. Clinical and Histopathological details were recorded, analysed and compared. Results: Of the 826 cases, Total abdominal hysterectomy was the most common surgery. The age varied from 21 to 85 with fourth decade as the most common age. Fibroid uterus and AUB were the most common clinical indication. Histopathology revealed leiomyoma as the most common diagnosis. About $95.5 \%$ cases correlated with clinical diagnosis. Of the 258 AUB cases, 100 had pure endometrial pathology and 31 cases showed combined endometrial and other pathologies. Conclusion: Histopathological evaluation is essential to substantiate the clinical findings, identify missed pathologies, establishing a definitive etiology thereby aiding effective treatment of the pathology.

Keywords: Hysterectomy, AUB, Endometrial Hyperplasia, Leiomyoma
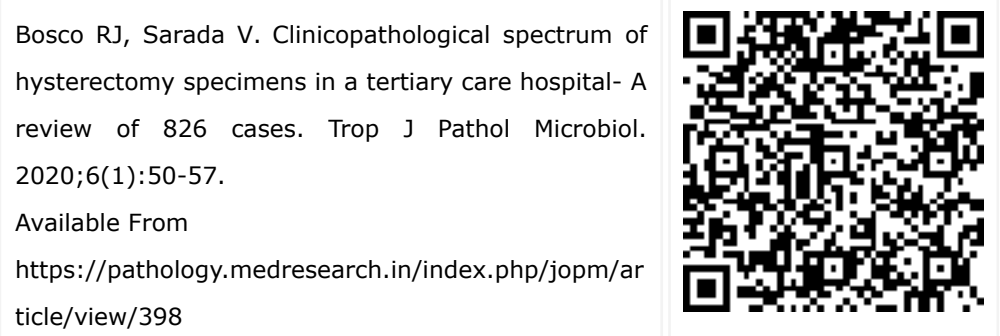

\section{Introduction}

Hysterectomy is one of the most commonly performed surgeries in the world[1]. Indications for hysterectomies include common conditions like Abnormal uterine bleeding, fibroid, adenomyosis, endometrial

Manuscript Received 20-12-2019

Conflict of Interest No
Lesions and less frequently tumors of female genital tract $[2,3]$. Types of hysterectomies done include subtotal hysterectomy, total abdominal hysterectomy with or without salphingoopherectomy, vaginal hysterectomy and laparoscopic method [4]. This study aims at identifying the distribution of the age, 
Clinical indications, various histopathological diagnosis and clinicopathological correlation of hysterectomy specimens.The diagnostic importance of histopathological evaluation of hysterectomy is well explained in patients of female genital tract cancers where adjuvant treatment is dependent on the grade, determination of targeted therapy and extent of invasion [5].

Histopathological examination of hysterectomy specimens, irrespective of clinical diagnosis is essential to study the associations between multiple lesions in female genital tract, to identify newer etilogies for the diseases and to study the effects of hormones in various parts of the female genital tract with its potential consequences. Abnormal uterine bleeding is one of the most important indication for hysterectomy [6].

Though leiomyoma and adenomyosis are frequent causes of AUB and can be diagnosed by ultrasonography, histopathology is essential to confirm these common benign causes and further helps to identify rare causes, hidden pathologies and to rule out malignancy in AUB $[7,8]$.

Dysfunctional uterine bleeding is a diagnosis of exclusion, where extensive histopathological examination of the female genital tract is essential to confirm the absence of organic cause for AUB. A variety of conditions also require the removal of uterus with no gross or microscopic pathology even after detailed examination, which includes treatment of ovarian, fallopian tube and vaginal malignancy, Pelvic inflammatory disease, endometriosis, pelvic pain and pelvic tuberculosis [9].

This study aims to anaylse in detail about the distribution and causes of AUB. The study also aims at identifying various histopathological patterns of endometrial, myometrial, cervical and ovarian lesions in cases presented as AUB.

\section{Material and Methods}

Setting:Department of pathology, Trichy SRM Medical College Hospital and Research Centre

Duration: January 2018 to November 2019

Type of study: Retrospective study

Sampling Size calculation: Based on previous studies and stastistical formula, sample size was determined with alpha error of 0.05 and power of 0.95

\section{Sample size: 826}

Inclusion criteria: All hysterectomy specimens received at the time of study period was included in the study.

Exclusion criteria: Hysterectomies with no adequate clinical data, hysterectomies done for trauma, hysterectomies done for systemic causes of bleeding.

Data collection procedure: Clinical data was recorded retrospectively. Microscopy was performed and histopathological details were recorded, analysed and compared with the clinical data.

Data analysis: Categorical variables was expressed as frequencies and percentages. Student $T$ test was applied for calculating statistical significance when data followed nominal distribution. Mann whitney test applied when data followed non nominal distribution. Nominal categorical data between the group was compared using Chi-square test or fisher's exact test as appropriate. $\mathrm{P}<0.05$ was taken to indicate a statistical significant difference.

\section{Results}

Total 826 cases of hysterctomy specimens were received during the study period. Of the 826 hysterctomies, total abdominal hysterectomy with bilateral salphingoopherectomy was the most common surgery done with 379 cases. Table 1 represented the summary of types of hysterectomy done in the study.

Table-1: Types of hysterectomy done in the present study.

\begin{tabular}{|l|l|l|}
\hline \multicolumn{1}{|c|}{ Types of hysterectomy } & $\begin{array}{r}\text { No of } \\
\text { cases }\end{array}$ & $\begin{array}{l}\text { Percenta } \\
\text { ge }\end{array}$ \\
\hline $\begin{array}{l}\text { Total abdominal hystectomy with bilateral } \\
\text { salphingoopherectomy }\end{array}$ & 379 & 45.9 \\
\hline Total abdominal hystectomy & 312 & 37.8 \\
\hline $\begin{array}{l}\text { Total abdominal hystectomy with unilateral } \\
\text { salphingoopherectomy }\end{array}$ & 61 & 7.3 \\
\hline Vaginal hysterectomy & 50 & 6.1 \\
\hline Radical hysterectomy & 24 & 2.9 \\
\hline Subtotal hysterectomy & 0 & 0 \\
\hline
\end{tabular}

The age range varied from 21 to 85 .

Fourth decade was the most common age group undergoing hysterectomy.

Table 2 represented the age distribution of hysterectomy in the present study. 
Table-2: Age distribution of hysterectomy.

\begin{tabular}{|l|l|l|l|l|l|l|l|l|}
\hline Age group & $10-19$ & $20-29$ & $30-39$ & $40-49$ & $50-59$ & $60-69$ & $70-79$ & 80 or more \\
\hline $\begin{array}{l}\text { No of } \\
\text { patients }\end{array}$ & 0 & 8 & 120 & 455 & 157 & 64 & 18 & 4 \\
\hline percentage & $0 \%$ & $1 \%$ & $14.5 \%$ & $55.1 \%$ & $19 \%$ & $7.7 \%$ & $2.2 \%$ & $0.5 \%$ \\
\hline
\end{tabular}

Fibroid uterus and AUB were the most common clinical indication for hysterectomy. Table 3 showed the summary of clinical indications for hysterectomy.

\section{Table-3: Clinical indications for hysterectomy.}

\begin{tabular}{|l|l|l|}
\hline \multicolumn{1}{|c|}{ Clinical diagnosis } & No of patients & Percentage \\
\hline AUB & 258 & 31.3 \\
\hline Fibroid & 226 & 27.5 \\
\hline Prolapse & 147 & 17.9 \\
\hline Adenomyosis & 102 & 12.5 \\
\hline Adnexal mass & 53 & 6.5 \\
\hline Polyp cervix & 13 & 1.7 \\
\hline Cervix mass & 9 & 1.2 \\
\hline Pelvic inflammatory disease & 6 & 0.7 \\
\hline Endometriosis & 6 & 0.7 \\
\hline Hirsutism with adnexal mass & 2 & 0.2 \\
\hline Post partumhemorrhage & 1 & 0.1 \\
\hline Vaginal cyst & 1 & 0.1 \\
\hline Leucoplakia & 1 & 0.1 \\
\hline Dysuria with abdominal distension & 1 & 0.1 \\
\hline
\end{tabular}

In histopathological diagnosis, leiomyoma was the most common diagnosis, followed by adenomyosis and degenerative changes consistent with prolapse.

Table 4 summarises the major histopathological findings(includes multiple diagnosis)of all hysterctomy specimens.

When correlation between clinical and histopathological diagnosis was made, 781 out of 826 cases correlated with clinical diagnosis (95.5\%). 45 cases did not show correlation with clinical diagnosis.

Most of the noncorrelating cases were microscopically adenomyosis, which clinically was diagnosed as leiomyoma or vice versa of the 258 cases presented as AUB, 100 cases had pure endometrial pathology and 31 cases showed combined endometrial with either myometrial or cervical pathology.

Table 5 showsbreakup of histopathology observed in AUB cases. In cases presented as AUB, the Summary of histopathological findings in cervix and vagina, endometrium, myometrium, ovary are shown in the Table 6,7,8 and 9 respectively.
Table-4: Summary of histopathological findings for all hysterectomy specimens

\begin{tabular}{|l|l|l|}
\hline \multicolumn{1}{|c|}{ Histopathological finding } & $\begin{array}{l}\text { No of cases } \\
\text { with finding }\end{array}$ & $\begin{array}{l}\text { Perce } \\
\text { ntage }\end{array}$ \\
\hline Leiomyoma & 307 & 37.5 \\
\hline Adenomyosis & 201 & 25.3 \\
\hline Prolapse & 147 & 17.8 \\
\hline Endometrial Hyperplasia & 76 & 9.2 \\
\hline $\begin{array}{l}\text { Benign ovarian cyst (including benign cystic } \\
\text { neoplasm) }\end{array}$ & 47 & 5.7 \\
\hline Disordered proliferative endometrium & & \\
\hline CIN & 40 & 4.8 \\
\hline Benign cervical polyp lesions & 27 & 3.4 \\
\hline Ovarian epithelial malignancy & 23 & 2.9 \\
\hline Ovarian stromal tumors & 20 & 2.4 \\
\hline Endometriosis & 14 & 1.7 \\
\hline Endometritis & 15 & 1.8 \\
\hline Endometrial carcinoma (including stromal tumor) & 12 & 1.4 \\
\hline Salphingoopheritis & 10 & 1.4 \\
\hline Carcinoma cervix & 8 & 1.2 \\
\hline Ovarian germ cell tumors & 5 & 1.0 \\
\hline Other malignant tumors (including malignant & 5 & 0.6 \\
\hline Mullerian tumor, leiomyosarcoma, vaginal dermoid) & & 0.6 \\
\hline Others & 4 & 0.5 \\
\hline
\end{tabular}

Table-5: Summary of histopathology observed in AUB

\begin{tabular}{|l|l|l|l|l|l|l|l|l|}
\hline \multicolumn{1}{|c|}{ Obstopathology } & $20-$ & $30-$ & $40-$ & $50-$ & $60-$ & $70-$ & Tot & $\begin{array}{l}\text { ercentag } \\
\text { al }\end{array}$ \\
\hline Endometrial & 0 & 10 & 61 & 26 & 2 & 1 & 100 & 38.8 \\
\hline $\begin{array}{l}\text { Adenomyosis+ } \\
\text { endometrial }\end{array}$ & 0 & 0 & 15 & 0 & 1 & 0 & 16 & 6.2 \\
\hline $\begin{array}{l}\text { Leiomyoma+ } \\
\text { endometrial }\end{array}$ & 0 & 0 & 11 & 2 & 0 & 0 & 13 & 5.0 \\
\hline Cervix+ endometrial & 0 & 2 & 0 & 0 & 0 & 0 & 2 & 0.7 \\
\hline Cervix & 0 & 3 & 15 & 3 & 0 & 0 & 21 & 8.1 \\
\hline Ovary & 0 & 0 & 6 & 4 & 0 & 0 & 10 & 3.9 \\
\hline Leiomyoma & 0 & 0 & 27 & 0 & 0 & 0 & 27 & 10.5 \\
\hline Adenomyosis & 3 & 6 & 18 & 7 & 0 & 0 & 34 & 13.2 \\
\hline Adenomyosis+ & 0 & 1 & 9 & 2 & 0 & 0 & 12 & 4.7 \\
\hline Leiomyoma & $1.2 \%$ & $8.5 \%$ & 71.7 & 17.1 & $1.2 \%$ & $0.3 \%$ & & 100 \\
\hline Vaginal & 0 & 0 & 1 & 0 & 0 & 0 & 1 & 0.4 \\
\hline Leiomyosarcoma & 0 & 0 & 2 & 0 & 0 & 0 & 2 & 0.8 \\
\hline No pathology identified & 0 & 0 & 20 & 0 & 0 & 0 & 20 & 7.7 \\
\hline Total & 3 & 22 & 185 & 44 & 3 & 1 & 258 & \\
\hline Percentage & & & $\%$ & $\%$ & & & & \\
\hline
\end{tabular}


Table-6: Summary of AUB cases with histopathological findings in cervix and vagina

\begin{tabular}{|l|l|l|}
\hline $\begin{array}{c}\text { Histopathological finding in } \\
\text { cervix and vagina }\end{array}$ & $\begin{array}{c}\text { No of } \\
\text { cases }\end{array}$ & $\begin{array}{c}\text { Percentage of AUB cases } \\
\text { with the lesion }\end{array}$ \\
\hline $\begin{array}{l}\text { Benign polyps of cervix (including } \\
\text { cervical leiomyoma) }\end{array}$ & 13 & 5.0 \\
\hline CIN & 2 & 0.7 \\
\hline Carcinoma cervix & 8 & 3.1 \\
\hline Vaginal teratoma & 1 & 0.4 \\
\hline
\end{tabular}

Table-7: Summary of AUB cases with histopathological findings in endometrium

\begin{tabular}{|l|l|l|}
\hline $\begin{array}{c}\text { Histopathological finding in } \\
\text { endometrium }\end{array}$ & $\begin{array}{c}\text { No of } \\
\text { cases }\end{array}$ & $\begin{array}{c}\text { Percentage of AUB cases } \\
\text { with the lesion }\end{array}$ \\
\hline Endometrial hyperplasia & 65 & 25.2 \\
\hline $\begin{array}{l}\text { Disordered proliferative } \\
\text { endometrium }\end{array}$ & 40 & 15.5 \\
\hline Cystic atrophic endometrium & 7 & 2.7 \\
\hline $\begin{array}{l}\text { Endometrial carcinoma (including } \\
\text { stromal tumor) }\end{array}$ & 10 & 3.9 \\
\hline Endometritis & 5 & 1.9 \\
\hline Hormone induced changes & 2 & 0.8 \\
\hline Malignant Mullerian tumor & 2 & 0.8 \\
\hline
\end{tabular}

Table-8: Summary of AUB cases with histopathological findings in myometrium

\begin{tabular}{|l|l|l|}
\hline $\begin{array}{c}\text { Histopathological finding in } \\
\text { myometrium }\end{array}$ & $\begin{array}{c}\text { No of } \\
\text { cases }\end{array}$ & \multicolumn{1}{|c|}{$\begin{array}{c}\text { Percentage of AUB cases } \\
\text { with the lesion }\end{array}$} \\
\hline Adenomyosis & 62 & 24 \\
\hline Leiomyoma & 52 & 20.2 \\
\hline Leiomyosarcoma & 2 & 0.8 \\
\hline
\end{tabular}

Table-9: Summary of AUB cases with histopathological findings in ovary

\begin{tabular}{|l|l|l|}
\hline $\begin{array}{c}\text { Histopathological finding } \\
\text { in ovary }\end{array}$ & $\begin{array}{r}\text { No of } \\
\text { cases }\end{array}$ & $\begin{array}{r}\text { Percentage of AUB cases with } \\
\text { the lesion }\end{array}$ \\
\hline $\begin{array}{l}\text { Benign ovarian cystic lesions } \\
\text { malignancy epithelial }\end{array}$ & 2 & 0.8 \\
\hline Ovarian stromal tumor & 6 & 0.4 \\
\hline Ovarian germ cell tumor & 1 & 0.4 \\
\hline
\end{tabular}

Table-10: Types of endometrial hyperplasia observed in the present study

\begin{tabular}{|l|l|l|l|l|l|l|l|}
\hline & $\begin{array}{r}\mathbf{2 0}- \\
\mathbf{2 9}\end{array}$ & $\begin{array}{r}\mathbf{3 0 -} \\
\mathbf{3 9}\end{array}$ & $\begin{array}{r}\mathbf{4 0 -} \\
\mathbf{4 9}\end{array}$ & $\begin{array}{c}\mathbf{5 0} \\
\mathbf{5 9}\end{array}$ & $\begin{array}{c}\mathbf{6 0} \\
\mathbf{6 9}\end{array}$ & $\begin{array}{c}\mathbf{7 0 -} \\
\mathbf{7 9}\end{array}$ & $\begin{array}{c}\text { Tota } \\
\mathbf{I}\end{array}$ \\
\hline $\begin{array}{l}\text { Simple hyperplasia without } \\
\text { atypia }\end{array}$ & 0 & 6 & 31 & 13 & 0 & 0 & 50 \\
\hline Simple hyperplasia with atypia & 0 & 0 & 2 & 0 & 0 & 0 & 2 \\
\hline $\begin{array}{l}\text { Complex hyperplasia with } \\
\text { atypia }\end{array}$ & 0 & 2 & 4 & 3 & 0 & 0 & 9 \\
\hline Cystoglandular hyperplasia & 0 & 0 & 1 & 9 & 3 & 2 & 15 \\
\hline Total & 0 & 8 & 38 & 25 & 3 & 2 & 76 \\
\hline
\end{tabular}

Of the 100 pure endometrial causes of AUB, 50 cases were endometrial hyperplasia, 28 were disordered proliferative endometrium, 10 endometrial carcinoma, 5 cystic atrophy, 5 were endometritis, one malignant mullerian tumor and one hormone induced changes. 15 cases of AUB had endometrial hyperplasia either combined with myometrial or cervical lesions.

Table 10 showed the types of endometrial hyperplasia (76) observed in the study that presented with AUB (65) and without AUB (11).

\section{Discussion}

Hysterectomy is one of the most commonly performed surgeries in the world usually done for the management of fibroid, Abnormal uterine bleeding, adenomyosis, prolapse and neoplastic lesions of the female genital tract $[2,14]$. Charles Clay performed the first subtotal hysterectomy in 1843 and the first total hysterectomy was done in 1929 in England $[1,10]$. Hysterectomies account for about $6 \%$ of all surgeries done in india [11]. Abdominal route is favourable in large fibroids, bulky uterus, suspected malignancy and emergencies for obstetric emergencies. Vaginal route commonly done in prolapse uterus and uterus weighing less than 280grams [12]. In the present study, a total of 826 hysterctomy cases were studied and total abdominal hysterectomy with bilateral salphingoopherectomy was the most common surgery done which is comparable with the previous study done by Subrata et al $(77.26 \%)$, Gousia Rahim et al (67.19\%), Kishwar et al (75\%), Gangadharan et al(72\%) and Bharati et al (76.75\%) [13- 16]. Toma et al, PL leung et al reported $78 \%$, $71 \%$ abdominal hysterectomies in their studies respectively $[17,18]$. Sujeet Kumar et al reported vaginal hysterectomy as the most common type of hysterectomy done [19].

The most common age group for hysterectomy in the present study was 40 to $49 \mathrm{yrs}$. This is comparable to the previous study by Subrata e al $(45.78 \%)$, Gousia Rahim et al $(47.27 \%)$, Gupta et al $(51.40 \%)$, Kishwar et al (45\%), Gangadharan et al and Bharati et al (41\%) $[5,9,10,13-15]$. Mean age for hysterectomy was 46.3 in a previous study by Jha $\mathrm{R}$ et al which is similar to the present study [20].

In the present study, $A \cup B$ and fibroid uterus were the most common clinical indication for hysterectomy followed by prolapse uterus. Previous 
Study done by Priyadarshini et al, Shergill SK et al, Subrata et al, Gousia Rahim et al, Sajitha et al, Gupta et al, Kishwar et al and Gangadharan et al all showed fibroid uterus, AUB and prolapse as the most common indication for hysterectomy $[5,10,13,14,15,21,22]$.

The histopathological study of the specimens in the present study revealed leiomyoma as the most common single histopathological finding observed in 310 cases. $37.5 \%$ hysterectomy cases had leiomyoma either as a predominant pathology or as a additional finding to another pathology. $25.3 \%$ cases had adenomyosis. Pevious studies reported similar findings ie.,leiomyoma and adenomyosis as the most common histopathological finding in their studies $[5,10,13,15,16,19]$. Khriesat et al reported adenomyosis as the most common finding in hysterectomy specimens with $37 \%$. Sajjad $M$ et al reported 39\% leiomyoma, 19\% adenomyosis and $5 \%$ dual pathologies $[24,25]$.

Endometrial hyperplasia was seen in $9.2 \%$ of all hysterectomy cases which is comparable with subrata et al (8.95\%). 50\% of cases of endometrial hyperplasia were in the age group 40-49 which is comparable to Sajitha et al [23]. The early identification of endometrial hyperplasia is important to prevent transformation to endometrial carcinoma which is found to be around 5-10\% [26]. High percentage of endometrial hyperplasia in the age group may be due to obesity, diabetes and sedentary lifestyle [27].

Incidence of malignancy in the hysterectomy specimens in this study was $7.75 \%$ which was comparable to Subrata et al $(7.68 \%)$ and Gupta et al $(4 \%)[10,13]$.

Overall incidence of endometrial carcinoma in hysterectomy specimens was found to be $1.21 \%$ which is similar comparable to Subrata et al. Overall incidence of ovarian tumors in hysterectomy specimens is $10.4 \%$ and benign tumors constituted $66.3 \%$ in the present study compared to Subrata et al which reported $8.42 \%$ tumors with $63.5 \%$ benign tumors [13].

Correlation of clinical diagnosis with the histopathologic diagnosis in the present study showed $94.5 \%$ correlation, that was comparable to study by Lee et al (80\%), Gupta et al and Gangadharan et al $(95 \%)[10,15,28]$. The high degree of correlation may be due to extensive preoperative clinical and radiological evaluation in the tertiary care hospital.
AUB is defined as menstrual bleeding with abnormal amount, frequency, duration or cyclicity of bleeding presenting as menorrhagia, polymenorrhoea and intermenstrual bleeding $[6,29]$. Routine non invasive investigations for $A \cup B$ include Complete blood count, platelet count, PT, APTT and LFT. In reproductive age group blood and urine beta HCG levels should be evaluated to rule out pregnancy related bleeding. Endocrine causes are ruled out by doing thyroid function test, FSH level, $\mathrm{LH}$ and prolactin. Blood investigations are followed by transvaginal ultrasonography with endometrial sampling and histopathological evaluation[30]. When organic lesion could not be identified as the cause of AUB, then Dysfunctional uterine bleeding is considered as the diagnosis [27]. In the present study, AUB was prevalent in age ranging from 20 to 79. $40-49$ years (69.7\%) was the most common age group presented with AUB. Sajitha et al reported prevalence in age ranging from 23 to 78 ; 45 to 55 was the most common age group (42.95\%)[23]. Mitali et al also reported 40- 45 age group as the most common age for AUB [29]. Most common age for $A \cup B$ correlated with many other previous studies $[19,27,31]$. AUB is common in the perimenopausal age, $[27,32,33,34]$ WHO defines perimenopausal age group as the period between 2 to 8 years preceding menopause and one yearafter the last mensus [35]. In the present study no organic lesions were identified in 20 AUB cases $(7.7 \%)$ and these cases were designated as Dysfunctional uterine bleeding.

Most common histopathology in AUB patients was due to endometrial pathology followed by adenomyosis and leiomyoma in the present study. Study by Sujeet et al showed leiomyoma, DUB and adenomyosis as the common cause for AUB [19]. Doraisamy Saraswathi et al reported DUB, disordered proliferative endometrium as the most common histopathological abnormality in AUB [27]. Endometrial hyperplasia was seen in 25.2\% (65 out of 258) cases of AUB in the present study. Sajitha et al reported $25 \%$ endometrial hyperplasia in AUB [23]. Mitali et al reported $12 \%$ in AUB [29]. Maximum age group for endometrial hyperplasia was 46-55 in a study by Sajitha et al, which is comparable to the present study [23]. Hyperplasia without atypia is considered benign and will usually regress with conservative management. But hyperplasia with atypia has $60 \%$ chances of coexisting with endometrial carcinoma or it may develop into endometrial carcinoma in a span of few years. 
So hysterectomy is the treatment of choice in these patients [36]. In the present study hyperplasia without atypia are subjected to hysterectomy due to failure of conservative treatment. In simple hyperlasia the gland stromal ratio is maintained, where as in complex hyperplasia gland stromal ratio is increased [37]. $15.5 \%$ showed disordered proliferative endometrium in AUB in the present study, which is comparable to study by Doraisamy Saraswathi et $\mathrm{al}(20.5 \%)$ and Sajitha et al(12.2\%) $[23,27] 24.03 \%$ of AUB cases showed adenomyosis which is similar comparable to sujeet et al [19]. Disordered proliferative endometrium is due to prolonged periods of anovulatory cycles leading to prolonged estrogen exposure in perimenopausal women. Histopathological appearance of endometrial hyperplasia and disordered proliferative endometrium are similar and a continum exists between the both, but the distinction is poorly reproducible. However the management of both conditions are the same with progesterone drugs. Histopathologically endometrium with many dilated glands that fulfills the microscopic criteria of endometrial hyperplasia are considered as endometrial hyperlasia, whereas disordered endometrium has very less number of cystically dilated glands [37]. Pattern of endometrial causes of AUB was statistically significant with $p$ value < 0.05. As a woman reaches menopause, cycles shorten and often becomes intermittently anovulatory due to the decline in the ovarian follicles and in estradiol levels to leading to various patterns of AUB [38].

In the present study, $11.6 \%$ AUB patients had malignancy and endometrial carcinoma comprised of $3.9 \%$ cases compared to study by Sajitha et al which showed $6.4 \%$ malignancy and $4.5 \%$ endometrial carcinoma[23].

Limitations of the study: Advanced cases of malignancy which are inoperable, yet had significant gynaecological symptoms could not be assesed as possible causes of AUB. Cases of AUB which were effectively managed by medical treatment and cases of AUB where preserving the uterus was a prime importance for preserving fertility could not be studied as the cause of AUB.

\section{Conclusion}

Hysterectomy is done for a large variety of gynaecological conditions. The importance of histopathological evaluation is the ability to
Substantiate the clinical findings and also to identify associated or missed pathologies, particularly malignancies thereby establishing a definitive etiology responsible for the clinical presentation and subsequently helping in the management of the condition.

\section{What the study adds to the existing knowledge?}

The present study identified high incidence of hysterectomy done for AUB, with histopathology revealing more than $50 \%$ of the AUB cases with endometrial pathology. Present study also showed higher incidence of endometrial hyperplasia and disordered proliferative endometrium. This increasing trend of endometrial pathology in AUB thereby leading to increase in hysterectomy procedures has to be evaluated in future studies with more sample size and additional relevant data.

\section{Contribution}

Dr. Ronald J Bosco and Dr. Sarada, Professor contributed in documentation of the microscopic findings, review of literature and discussion of the present study. The authors read and signed the final paper.

\section{Reference}

01. Subrata P, Srabani C,Anuradha $S$ et al. A retrospective clinico-pathological study of hysterectomy cases in a tertiary care hospital in India- A review of 950 cases. Bang J Med Sci. 2018;17(1)88-92.

doi:

[Article:https://doi.org/10.3329/bjms.v17i1.35287]

[Crossref]

02. Prasad DR, Nair NV. Retrospective analysis of elective hysterectomy cases in a tertiary care centre. Int J Reprod Contracept Obstet Gynecol. 2018;7(9)3714-3717.

doi: [Article:http://dx.doi.org/10.18203/23201770.ijrcog20183782][Crossref]

03. Veena S Naik, Jyoti D Rege, Kusum D Jashnavi. Pathology of genital tract in post menopausal bleeding, Dept of Pathology, TN Medical college and BYL nairch, Hospital, Mumbai. Bombay Hosp J. 1996.

[Crossref] 
04. Nausheen F, Iqbal J, Bhatti FA, Khan AT, Sheikh S. Hysterectomy- The patient's perspective. Annals Gynecol. 2004;10(4)339-341.

doi:

[Article:https://doi.org/10.21649/akemu.v10i4.1220] [Crossref]

05. Wu JM, Wechter ME, Geller EJ. Hysterectomy rates in the United States 2003. Obstet Gynecol. 2007;100(5)1091-1095.

doi:

[Article:https://doi.org/10.1097/01.AOG.0000285997 .38553.4b][Crossref]

06. Kishwar N, Abid H, Riasat A. Clinico-pathological study of hysterectomy at Pak Red Crescent medical and dental college. JIIMC. 2018;13(2).

[Crossref]

07. Cote I, Jacobs P, Cumming DC. Use of health services associated with increased menstrual loss in the United States. Am J Obstet Gynecol. 2003;188(2)343-348.

doi: [Article:https://doi.org/10.1067/mob.2003.92] [Crossref]

08. Toma A, Hopman WM, Gorwill RH. Hysterectomy at a Canadian tertiary care facility- results of a 1 year retrospective review. BMC Women's health. 2004;4-10.

doi: [Article:https://doi.org/10.1186/1472-6874-410][Crossref]

09. Thompson JD. Hysterectomy In-Thompson JD, Rock JA, eds, Te Linde's Operative Gynecology. 7th ed, JB Lippincott Company, Philadelphia. 1992;663-738.

[Crossref]

10. Gupta G, Kotasthane D, Kotasthane V. Hysterectomy- A clinic-pathological correlation of 500 cases. Int J Gynec and Obstet. 2010;14(1).

[Crossref]

11. Singh A, Arora AK. Why hysterectomy rates are lower in India?. Ind $\mathrm{J}$ Commun Med. 2008;33(3)196-197.

doi: [Article:https://dx.doi.org/10.4103\%2F09700218.42065][Crossref]

12. Kovac Sr. Hysterectomy outcomes in patients with similar indications. Obstet Gynecol. 2000;95(6 pt 1)787-793.

doi: [Article:https://doi.org/10.1016/s00297844(99)00641-9][Crossref]
13. Sutton C. Hysterectomy- a historical perspective. Baillieres Clin Obstet Gynaecol. 1997;11(1)1-22.

doi: [Article:https://doi.org/10.1016/s09503552(97)80047-8][Crossref]

14. Mandal SK. Clinico-pathological correlation of hysterectomy specimen for abnormal uterine bleeding in perimenopausal women. J Med Sci Clinic Res. 2017;5(1).

doi:

[Article:https://dx.doi.org/10.18535/jmscr/v5i1.125]

[Crossref]

15. Gangadharan V, Prasanthi C. Hysterectomy- a clinicopathological correlation in a rural setting. Indian J Bas App Med Res. 2016;5(2)8-15.

[Crossref]

16. Mishra B, Bhol SK. Study of clinical and pathological correlation of AUB patients undergoing hysterectomy. MedPulse- Int J Gynaecol. 2017; 3(1)13-18.

[Crossref]

17. Rimza ME. Dysfunctional uterine bleeding. Pediatr Rev. 2002;23(7)227-233.

doi: [Article:https://doi.org/10.1542/pir.23-7-227] [Crossref]

18. Leung PL. An audit on hysterectomy for benign diseases in public hospitals in Hong Kong. HK Med J. 2007;13(3)187-193.

[Crossref]

19. Gousia RR, Yudhir G, Subash B. Patterns of lesions in hysterectomy specimen- a prospective study. JK Sci. 2013;15(2).

[Crossref]

20. Jha R, Pant AD, Jha A, Adhikari RC, Sayami G. Histopathological analysis of hysterectomy specimens. J Nepal Med Assoc. 2006;45(163)283-290.

[Crossref]

21. Sajitha K, Shetty KP, Jayaprakash S, et al. Study of histopathological patterns of endometrium in abnormal uterine bleeding. CHRISMED J Health Res. 2014;1(2)76-81. [Crossref]

22. Priyadarshini Ph, Gomathi E. Clinicopathological study of uterine leiomyomas in hysterectomy specimens- A retrospective study. Int J Adv Res. 2018;6(2)571-576.

doi:[Article:http://dx.doi.org/10.21474/IJAR01/6474] [Crossref] 
23. Shergill SK, Shergill HK,Gupta $M$ et al. Clinicopathological study of hysterectomies. J Indian Med Assoc. 2002;100(4)238-239.

[Crossref]

24. Khreisat B, Al- Rawabdeh S, Duqoum W. Adenomyosis- Frequency of hysterectomy in histopathological specimens at two Jordanian military hospitals. JRMS. 2011;18(2)76-79.

[Crossref]

25. Sajjad M, Iltaf S, Qayyun S. Pathological findings in hysterectomy specimens of patients presenting with menorrhagia in different age groups. Am Pak Inst Med Sci. 2011;7;160-162. [Crossref]

26. Doraiswami S, Johnson T, Rao S, Rajkumar A, Vijayaraghavan J, Panicker VK. Study of endometrial pathology in abnormal uterine bleeding. J Obstet Gynecol India. $2011 ; 61(4) 426-430$.

doi: [Article:https://dx.doi.org/10.1007\%2Fs13224011-0047-2][Crossref]

27. Baak JP, Mutter GL. EIN and WHO 94. J Clin Pathol. 2005;58;1-6.

doi:

[Article:https://doi.org/10.1136/jcp.2004.021071] [Crossref]

28. Lee NC, Dicker RC, Rubin GL, Ory HW. Confirmation of pre-operative diagnosis for hysterectomy. Am J Obstet Gynecol. 1984;150(3)283-287.

doi: [Article:https://doi.org/10.1016/s00029378(84)90366-1][Crossref]

29. Khan S, Hameed S, Umber A. Histopathological pattern of endometrium on diagnostic $D$ and $C$ in patients with abnormal uterine bleeding. Annals. 2011;17(2)166-170.

doi:

[Article:https://doi.org/10.21649/akemu.v17i2.293]

[Crossref]

30. Talukdar B, Mahela S. Abnormal uterine bleeding in perimenopausal women- Correlation with sonographic findings and histopathological examination of hysterectomy specimen. J MidLife Health. 2016;7(2)73-77.

doi: [Article:https://doi.org/10.4103/09767800.185336][Crossref]
31. Mc Cluggage WG. My approach to the interpretation of endometrial biopsies and curettings. J Clin Pathol. 2006;59(8)801-812. doi:

[Article:https://doi.org/10.1136/jcp.2005.029702] [Crossref]

32. Mazur MT, Kurman RJ. Normal endometrium and infertility evaluation, In- Mazur MT, Kurman RJ,eds, Diagnosis of endometrial biopsy and curettings- A practical approach. 2nd ed, New York- Springer Verlag. 2005;p7-33.

[Crossref]

33. Albers JR, Hull SK, Wesley RM. Abnormal uterine bleeding. Am Fam Phys. 2004;69;1915-1926.

[Crossref]

34. Emons G, Beckmann MW, Schmidt D, Mallmann P. Uterus commission of the Gynecological Oncology Working Group (AGO), New WHO Classification of Endometrial Hyperplasias. Geburtshilfe Frauenheilkd. 2015;75(2)135-136. doi: [Article:https://doi.org/10.1055/s-00341396256][Crossref]

35. Muzaffar M, Akhtar KA, Yasmin S, Mahmood-UrRehman, Iqbal $W$, Khan MA. Menstrual irregularities with excessive blood loss- A clinicopathological correlation. J Pak Med Assoc. 2005;55(11)486-489.

[Crossref]

36. Bhosle A, Fonseca A. Evaluation and histopathological correlation of Abnormal uterine bleeding in perimenopausal women. Bombay Hosp J. 2010;52(1)69-72.

[Crossref]

37. Mitali M, Pratima M. Clinico-pathological evaluation of abnormal uterine bleeding. J Health Res Rev. 2015;2(2)45-59.

doi: [Article:https://doi.org/10.4103/23942010.160904][Crossref]

38. Goldstein SR. Menorrhagia and abnormal bleeding before the menopause. Best Pract Res Clin Obstet Gynecol. 2004;18(1)59-69. doi:

[Article:https://doi.org/10.1016/j.bpobgyn.2003.10.0 03][Crossref] 